\title{
Histological and immunohistochemical practical studies of canine cutaneous tumors
}

\author{
DONATAS ŠIMKUS, SAULIUS PETKEVIČIUS, GEDIMINAS PRIDOTKAS*, \\ LIGITA ZORGEVICA-POCKEVIČA**, VIKTORAS MASKALIOVAS*, \\ VIRGINIJA ŠIMKIENË*, ALIUS POCKEVIČIUS
}

\begin{abstract}
Department of Infectious Diseases, Veterinary Academy, Lithuanian University of Health Sciences, Tilzes Str. 18, LT-47130 Kaunas, Lithuania

*National Food and Veterinary Risk Assessment Institute, J. Kairiukscio Str. 10, LT-08409 Vilnius, Lithuania

${ }^{* *}$ Dr. L Kriaučeliūnas Small Animal Clinic, Veterinary Academy, Lithuanian University of Health Sciences, Tilzes Str. 18, LT-47130 Kaunas, Lithuania
\end{abstract}

\section{Šimkus D., Petkevičius S., Pridotkas G., Zorgevica-Pockeviča L.,} Maskaliovas V., Šimkienè V., Pockevičius A.

\section{Histological and immunohistochemical practical studies of canine cutaneous tumors}

\section{Summary}

A total of one hundred and fifty-three canine cutaneous tumors were examined and analyzed using the standard haematoxylin-eosin staining method. Additionally, tumors were examined immunohistochemically (41.4\%) with antibodies LP34, AE1/AE3, V9 and histochemically (24.8\%) with toluidine blue. Epithelial and melanocytic tumors of the skin accounted for $52.3 \%$ and mesenchymal tumours constituted $47.7 \%$. All epidermal and follicular tumors demonstrated positive immunostaining for "LP34" antibodies. Fibromas and fibrosarcomas, which were immunohistochemically positive for antibodies "V9", demonstrated negative immunostaining for antibodies "LP34". As many as 47.4\% of all round cell tumors showed positive staining with toluidine blue. Antibodies "LP34" are helpful for the differential diagnosis of epithelial cells of tumors in canine skin, skin adnexal and subcutaneous tissues. Antibodies "AE1/AE3" could be helpful for detecting metastatic glandular epithelial cells in the skin. Moreover, antibodies "V9" could be a useful tool to diagnose the cutaneous tumors consisting of fibrous tissue cells. Staining round cell tumors with toluidine blue may give valuable information on regarding mast cell tumors.

Keywords: canine cutaneous tumors, histology, immunohistochemistry, LP34, AE1/AE3, V9

The skin is strongly affected by external physical and chemical factors leading to the formation of canine cutaneous tumors (22), which have similar morphology, sometimes resulting in confusing pathological diagnoses $(13,17)$. A precise morphological identification of the origin and type of tumor cells makes it possible to identify and treat this disease in its early stages (3). The diagnosis of cutaneous tumors depends on histological features; however, immunohistochemistry is a very important auxiliary tool for a definitive diagnosis of the tumor $(1,12)$. It is also the basic most effective technique for determining the origin of a tissue or the differentiation of neoplastic cells (12). In immunohistochemistry, stained monoclonal antibodies are used to detect the presence of specific antigens (specific protein molecules) in tissues and cells, to identify their precise location and, according to the intensity of a staining reaction, to determine their approximate concentration $(12,25)$.
The most popular markers used for the differentiation of canine cutaneous tumors are specific antibodies against cytokeratin and vimentin proteins $(12,18,21)$.

Cytokeratins are components of the intermediate filament network of epithelial cells $(5,11,19)$. Up to $85 \%$ of the total content of the keratinocytes is composed of cytokeratins $(11,24)$. Vimentin is an intermediate filament protein that is expressed in most mesenchymal cells, especially in fibroblasts (14). Fibroblasts are critical for tissue homeostasis, and their inappropriate proliferation and activation can result in common and debilitating conditions, including fibrosis and cancer (15). In addition, vimentin is found in sarcomas, melanomas, sometimes in lymphomas and even in carcinomas (4).

The aim of the present study was to investigate canine cutaneous tumors by histological and immunohistochemical examination during routine diagnostics. 


\section{Material and methods}

The specimens of canine cutaneous tumors were selected randomly after surgical treatment of dogs at the veterinary clinics. $10 \%$ formalin buffer solution was used as the fixative. The tumor specimens were prepared for histological examination using a tissue processor (Shandon Pathcentre, UK, 2004). Paraffin blocks were made using paraffin block embedding centre (CD 1000, Italy, 2004). The paraffin blocks were cut into $4 \mu \mathrm{m}$ thick sections by means of a semiautomated microtome (Shandon Finesse ME, JK, 2004).

Histology. Histological examination was performed by staining every specimen of a tumor with haematoxylin-eosin. The histological features in stained specimens were detected using a light microscope (Zeiss Axioplan 2 imaging, Carl Zeiss Light Microscopy, Germany, 2004), described and photographed (Olympus DP12-2). The histological diagnosis of the tumor was established after the histopathological and immunohistochemical evaluation of research results. Round cell tumors were additionally stained with toluidine blue (Tab. 2).

Immunohistochemistry. Immunohistochemical examination was used as an additional test for the differentiating cutaneous tumor diagnoses.

Antibodies "LP34" were used for detecting the epithelial cells, antibodies "AE1/AE3" were used for detecting the metastatic mammary epithelial cells and hair matrix cells. Antibodies "V9" were used for detecting the fibrous tissue cells in cutaneous tumors (Tab. 1 and 2).

Immunohistochemical reactions were performed using the commercial bath "VECTASTAIN Elite ABC". Prior to carrying out the immunohistochemical reaction, paraffin embedded sections were mounted on the poly L-lysine microscope slides, and incubated for $30 \mathrm{~min}$ at $60^{\circ} \mathrm{C}$ until the paraffin melted. Then the specimens were deparaffinized in xylene twice for $5 \mathrm{~min}$ and dehydrated in isopropyl alcohol twice for $5 \mathrm{~min}$. The endogenous peroxidase activity was blocked with $3 \%$ hydrogen peroxide in methanol. Epitope unmasking was carried out in citrate buffer solution $(\mathrm{pH}-$

Tab. 1. Markers used for IHC staining

\begin{tabular}{|l|c|c|c|}
\hline \multicolumn{1}{|c|}{ Antibody specificity } & Clone & Antibody dilution & Supplier \\
\hline Cytokeratin HMW $(5,6,18)$ [LP34] & LP34 & $1: 100$ & LEICA/Novocastra, UK \\
Cytokeratin PAN [AE1/AE3] & AE1/AE3 & $1: 100$ & LEICA/Novocastra, UK \\
Vimentin [V9] & V9 & $1: 100$ & LEICA/Novocastra, UK \\
\hline
\end{tabular}

Tab. 2. The percentage of immunohistochemically and histochemically examined $(n=101)$

\begin{tabular}{|c|c|c|c|c|c|c|c|c|}
\hline & \multicolumn{2}{|c|}{ LP34 } & \multicolumn{2}{|c|}{ AE1/AE3 } & \multicolumn{2}{|c|}{ V9 } & \multicolumn{2}{|c|}{ Toluidine blue } \\
\hline & $\%$ & Results & $\%$ & Results & $\%$ & Results & $\%$ & Results \\
\hline Epithelial tumors of the skin & 13.1 & + & 2.0 & + & \multicolumn{2}{|c|}{ ND } & \multicolumn{2}{|c|}{ ND } \\
\hline Melanocytic tumours of the skin & 0.7 & - & \multicolumn{2}{|c|}{ ND } & \multicolumn{2}{|c|}{ ND } & \multicolumn{2}{|c|}{ ND } \\
\hline Fibrous tissue tumors of the skin & 5.9 & - & \multicolumn{2}{|c|}{ ND } & 5.9 & + & \multicolumn{2}{|c|}{ ND } \\
\hline Cutaneous rounds cells tumors & 9.8 & - & \multicolumn{2}{|c|}{ ND } & \multicolumn{2}{|c|}{ ND } & $\begin{array}{l}11.7 \\
13.1\end{array}$ & $\begin{array}{l}+ \\
-\end{array}$ \\
\hline Tumors metastatic to the skin & 2.0 & - & 2.0 & + & \multicolumn{2}{|c|}{ ND } & \multicolumn{2}{|c|}{ ND } \\
\hline Total & 31.5 & - & 4.0 & - & 5.9 & - & 24.8 & - \\
\hline
\end{tabular}

Explanations: $\%=$ percentage of examined cases; $+=$ positive reaction; $-=$ negative reaction; $\mathrm{ND}=$ not done
6.1 ) in the autoclave for $30 \mathrm{~min}$ at $121^{\circ} \mathrm{C}$. After autoclaving, the specimens were allowed to cool in citrate buffer solution at room temperature for $20 \mathrm{~min}$. The immunological staining reactions were performed using the "Shandon Sequenza" slide rack and a disposable cover-plate incubation system. Primary antibodies were incubated for one hour at room temperature. Tris-Buffered Saline and Tween 20 (TBST), $\mathrm{pH} 7.6$, was used for rinsing the sections. The immunoreactivity was visualized using 3.3'-diaminobenzidine (DAB) and hydrogen peroxide solution. Following the immunological reaction, the tumor specimens were counterstained with Mayer's haematoxylin, dehydrated in isopropyl alcohol, cleared in xylene and covered with cover clips. During each immunohistochemical reaction, positive and negative control specimens were used. A positive control specimen was used for negative control; however, in carrying out the reaction primary antibodies were omitted. The definitive diagnosis of a tumor was made on the basis of the results of histological and immunohistochemical examinations. Our specimens of canine cutaneous tumors were classified according to the World Health Organization (WHO) international histological classification of skin, melanocytic and soft tissue tumors of domestic animals (28). The statistical analysis was performed using Microsoft Office Excel 2007.

\section{Results and discussion}

Tumors occurrence. Occurrence of tumors in dogs was determined after examining and analyzing one hundred and fifty-three canine cutaneous tumors. Additionally, immunohistochemical reactions with specific different antibodies were performed. The results obtained are summarized in Tab. 2.

Skin epithelial and melanocytic tumors accounted for $52.3 \%$ and mesenchymal tumors constituted $47.7 \%$ of the total (Tab. 3 and 4).

All tumors originated from the epidermal cells, skin adnexal (hair, hair follicles, sebaceous glands, modified sebaceous glands and sweat glands) and skin melanocytes were classified as epithelial and melanocytic tumors of the skin. The skin cyst and metastases from other tumors to the skin were included in this group. The distribution of the incidence of epithelial and melanocytic tumors of the skin was as follows: tumors with adnexal differentiation reached $66.3 \%$, tumors of the epidermis accounted for $15.0 \%$, cysts amounted to $8.8 \%$ and epithelial tumors without squamous or adnexal differentiation were equal to $3.8 \%$, melanocytic tumors represented $3.8 \%$ and tumors metastatic to the skin stood at $2.5 \%$ (Tab. 3).

All tumors localized in the skin that were associated with soft tissues 
Tab. 3. Prevalence of epithelial and melanocytic tumors of the skin $(n=80)$

\begin{tabular}{|c|c|c|c|c|c|}
\hline Individual groups of tumors & $\%$ a & $\%^{b}$ & Individual groups of tumors cells & $\%^{b}$ & Individual types of tumor \\
\hline \multirow{2}{*}{$\begin{array}{l}\text { Epithelial tumors without squamous } \\
\text { or adnexal differentiation }\end{array}$} & \multirow{2}{*}{2.0} & \multirow{2}{*}{3.8} & \multirow{2}{*}{ Basal cell tumor } & \multirow{2}{*}{3.8} & Basal cell tumor (solid type) \\
\hline & & & & & Basal cell tumor (cystic type) \\
\hline \multirow{3}{*}{ Tumors of the epidermis } & \multirow{3}{*}{7.8} & \multirow{3}{*}{15.0} & \multirow{3}{*}{ Tumors of the epidermis } & \multirow{3}{*}{15.0} & Squamous cell carcinoma \\
\hline & & & & & Papilloma \\
\hline & & & & & Basosquamous carcinoma \\
\hline \multirow{19}{*}{ Tumors with adnexal differentiation } & \multirow{19}{*}{34.6} & \multirow{19}{*}{66.3} & \multirow{9}{*}{ Follicular tumors } & \multirow{9}{*}{31.3} & Infundibular keratinizing acanthoma \\
\hline & & & & & Trichoepithelioma \\
\hline & & & & & Trichoblastoma (ribbon type) \\
\hline & & & & & Trichoblastoma (medusoid type) \\
\hline & & & & & Trichoblastoma (granular cell type) \\
\hline & & & & & Trichoblastoma (spindle cell type) \\
\hline & & & & & Malignant trichoepithelioma (matrical carcinoma) \\
\hline & & & & & Pilomatricoma \\
\hline & & & & & Malignant pilomatricoma \\
\hline & & & \multirow{5}{*}{$\begin{array}{l}\text { Sebaceous and modified } \\
\text { sebaceous gland tumors }\end{array}$} & \multirow{5}{*}{22.5} & Sebaceous adenoma \\
\hline & & & & & Hepatoid gland adenoma \\
\hline & & & & & Hepatoid gland carcinoma \\
\hline & & & & & Meibomian adenoma \\
\hline & & & & & Sebaceous epithelioma \\
\hline & & & \multirow{4}{*}{$\begin{array}{l}\text { Apocrine and modified apocrine } \\
\text { gland tumors }\end{array}$} & \multirow{4}{*}{11.3} & Apocrine adenoma \\
\hline & & & & & Complex and mixed apocrine adenoma \\
\hline & & & & & Apocrine carcinoma \\
\hline & & & & & Ceruminous adenoma \\
\hline & & & Eccrine (atrichial) tumours & 1.3 & Eccrine carcinoma \\
\hline \multirow{2}{*}{ Cysts } & \multirow{2}{*}{4.6} & \multirow{2}{*}{8.8} & \multirow{2}{*}{ Cysts } & \multirow{2}{*}{8.8} & Infundibular cyst \\
\hline & & & & & Dermoid cyst \\
\hline Tumors metastatic to the skin & 1.3 & 2.5 & Tumors metastatic to the skin & 2.5 & Metastatic of mammary gland tumors to the skin \\
\hline Melanocytic tumors & 2.0 & 3.8 & Melanocytic tumors & 3.8 & Melanocytoma \\
\hline Total & 52.3 & 100 & & 100 & \\
\hline
\end{tabular}

Explanations: ${ }^{a}=$ prevalence of percentage among total tumors of the skin; ${ }^{b}=$ prevalence of percentage among epithelial and melanocytic tumors of the skin

and originated from round cells, adipose, fibrous, vascular and other miscellaneous connective tissues were classified as mesenchymal tumors of the skin. The distribution of the incidence of mesenchymal tumors of the skin was as follows: $28.6 \%$ of tumors of fibrous tissue, $24.7 \%$ of histiocytic tumors, $24.7 \%$ of mast cell tumors, $12.4 \%$ tumors of adipose tissue, $6.9 \%$ of other miscellaneous connective tissue tumors and $2.7 \%$ of tumors of vascular tissue respectively (Tab. 4).

Histological examination. Among the basal cell tumors two tumors were of the solid type and one tumor showed central cystic degeneration (cystic type) composed of hyperchromatic cells resembling the basal cells of normal epidermis. Squamous cell carcinomas composed of invasive cords of various degrees atypical keratinocytes resembling the stratum spinosum cells with
Tab. 4. Prevalence of mesenchymal tumors of the skin $(n=73)$

\begin{tabular}{|c|c|c|c|c|}
\hline Individual groups of tumors & $\%^{\mathrm{a}}$ & $\%^{\mathrm{b}}$ & Individual types of tumor & $\%^{\mathrm{b}}$ \\
\hline \multirow{4}{*}{ Tumors of fibrous tissue } & \multirow{4}{*}{13.7} & \multirow{4}{*}{28.6} & Fibrosarcoma & 12.3 \\
\hline & & & Collagenous hamartoma & 6.8 \\
\hline & & & Fibroma & 6.8 \\
\hline & & & Myxoma & 2.7 \\
\hline Histiocytic tumors & 11.8 & 24.7 & Canine cutaneous histiocytoma & 24.7 \\
\hline \multirow{2}{*}{ Mast cell tumors } & \multirow{2}{*}{11.8} & \multirow{2}{*}{24.7} & Mast cell tumor, grade II & 19.2 \\
\hline & & & Mast cell tumor, grade III & 5.5 \\
\hline \multirow{2}{*}{ Tumors of adipose tissue } & \multirow{2}{*}{5.9} & \multirow{2}{*}{12.4} & Lipoma & 11.0 \\
\hline & & & Infiltrative lipoma & 1.4 \\
\hline \multirow{4}{*}{$\begin{array}{l}\text { Other miscellaneous } \\
\text { connective tissue tumors }\end{array}$} & \multirow{4}{*}{3.2} & \multirow{4}{*}{6.9} & Chondrosarcoma & 2.7 \\
\hline & & & Carcinosarcoma & 1.4 \\
\hline & & & Cutaneous plasmacytoma & 1.4 \\
\hline & & & Transmissible venereal tumor & 1.4 \\
\hline Tumors of vascular tissue & 1.3 & 2.7 & Hemangioma & 2.7 \\
\hline Total & 47.7 & 100 & & 100 \\
\hline
\end{tabular}

Explanations: ${ }^{\mathrm{a}}=$ prevalence of percentage among total tumors of the skin; $\mathrm{b}=$ prevalence of percentage among mesenchymal tumors of the skin 


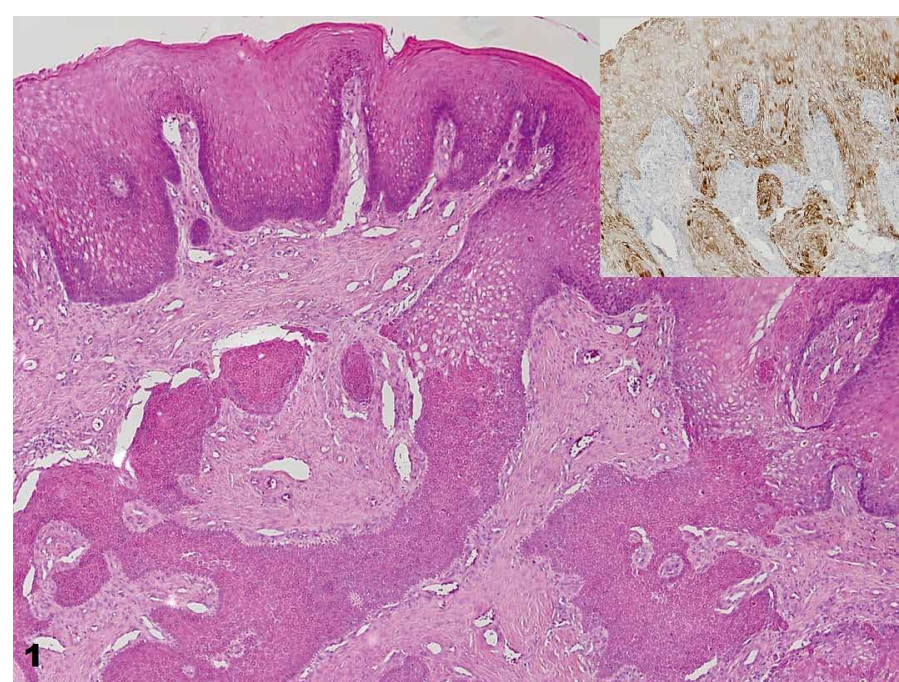

Fig. 1. Basosquamous carcinoma $(\mathrm{HE}, 40 \times$; inset positive immunostaining for cytokeratin LP34, $40 \times$ )

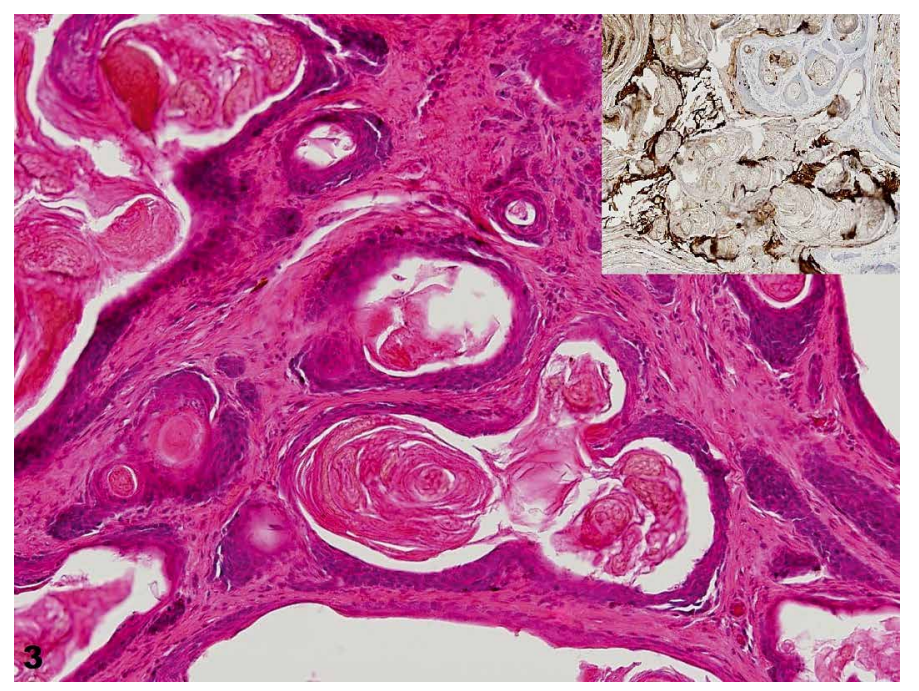

Fig. 3. Trichoepithelioma $(\mathrm{HE}, 100 \times$; inset positive immunostaining for cytokeratin LP34, $100 \times$ )

some epithelial cells and accumulated in the derma where they occur as multi-layered round keratin mass - "keratin pearls" - were prevalent among the tumors of the epidermis. Also, two papillomas composed of papillae supported by dermal fibrovascular stroma and enveloped in a layer of the well-differentiated hyperkeratotic stratified squamous epithelium and one basosquamous carcinoma composed of the accumulations of basal cells with foci for keratinising and squamous cells of derma layer in the centre (Fig. 1) were identified. Among the follicular tumors, trichoblastomas composed of the primary rudimentary hair matrix cells with giant basophilic nuclei and small distinct nucleoli were dominant. According to morphological features, the most common trichoblastoma was ribbon type (Fig. 2). Also, six infundibular keratinizing acanthomas composed of the neoplastic basaloid epithelial cells, resembling the normal follicular infundibulum cells, six trichoepitheliomas composed of the inner and outer sheath cells of the inferior region and the hair matrix cells (Fig. 3) and three pilomatricomas

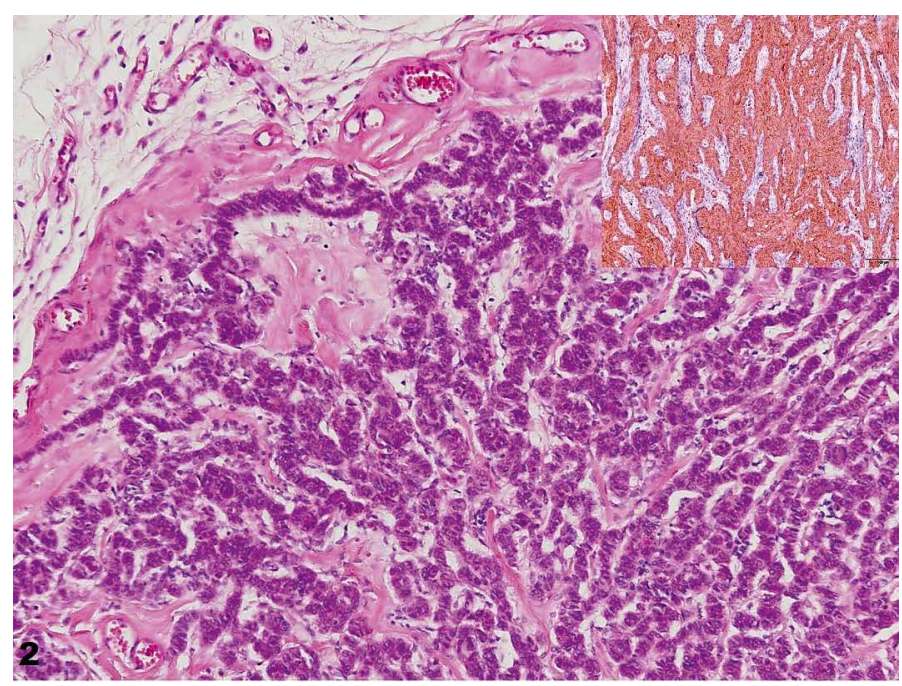

Fig. 2. Trichoblastoma (ribbon type) $(\mathrm{HE}, 100 \times$; inset positive immunostaining for cytokeratin AE1/AE3, $100 \times$ )

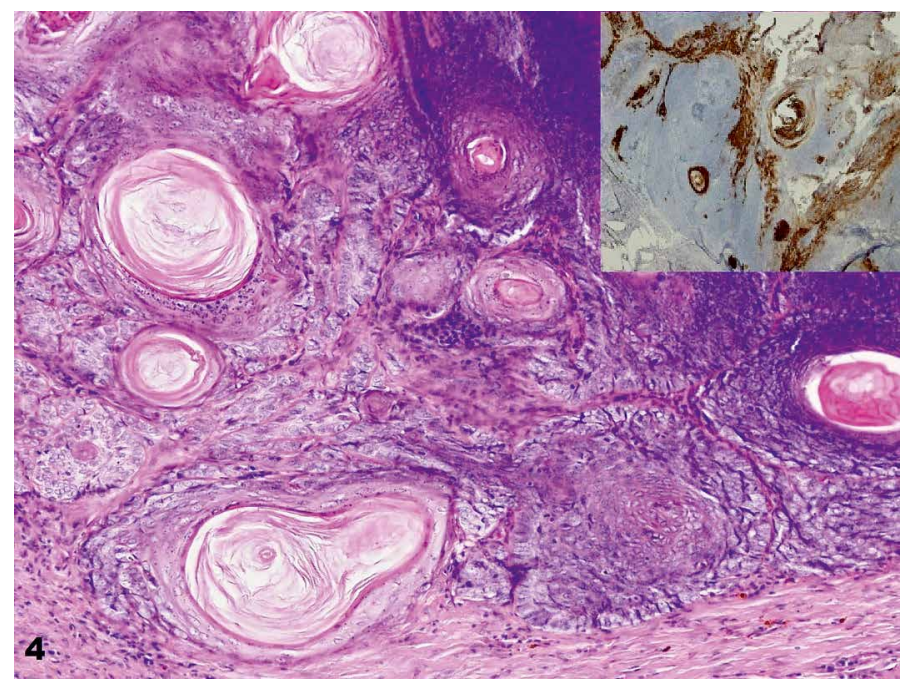

Fig. 4. Malignant trichoepithelioma $(\mathrm{HE}, 100 \times$; inset positive immunostaining for cytokeratin LP34, $50 \times$ )

composed of the hair matrix cells were identified. In all cases of infundibular keratinizing acanthoma, trichoepithelioma, pilomatricoma contained multiple cystic formations filled with keratin. One infundibular keratinizing acanthoma filled with keratin mass characteristic of squamous cell carcinoma but dominated by the basal cells surrounding the tumor was identified. Moreover, one trichoepithelioma with malignancy symptoms (abundant basophilic cells with the hyperchromic nucleus, a small amount of eosinophilic cytoplasm and keratinized foci in the intracellular material) was identified (Fig. 4). One pilomatricoma was diagnosed as malignant. Its histological structure resembled benignant pilomatricoma, though the lesion infiltrated the derma and subcutaneous tissues. Among the sebaceous and modified sebaceous gland tumors, the most common ones were sebaceous gland adenoma composed of the hyperplastic sebaceous gland cells invasive into the derma tissues, and hepatoid gland adenoma (perianal gland adenoma) composed of the tumor cells, morphologically resembling hepatocytes. 


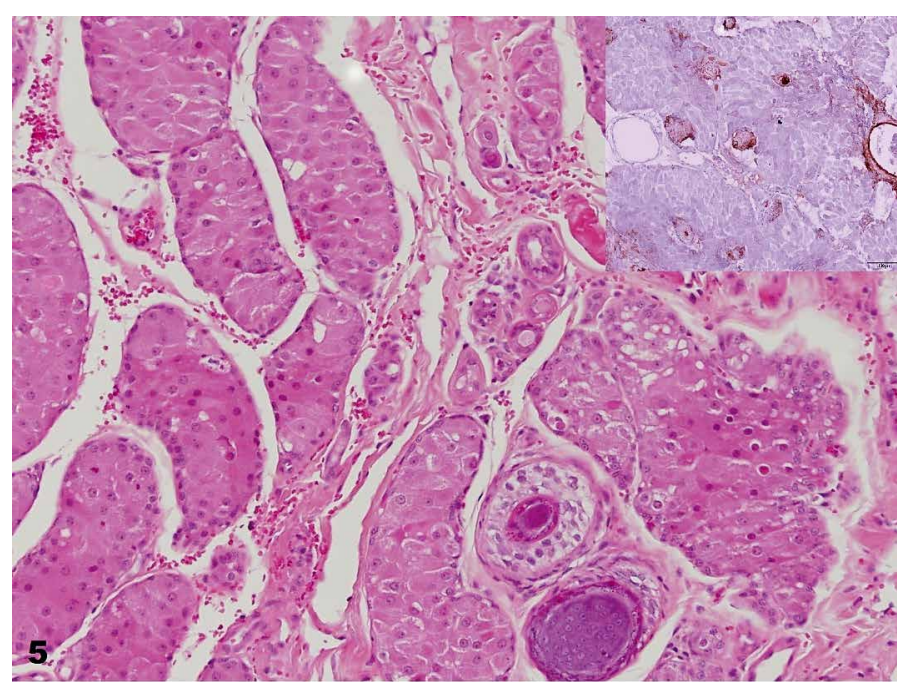

Fig. 5. Hepatoid gland adenoma (HE, $100 \times$; inset positive immunostaining for cytokeratin LP34, $100 \times$ )

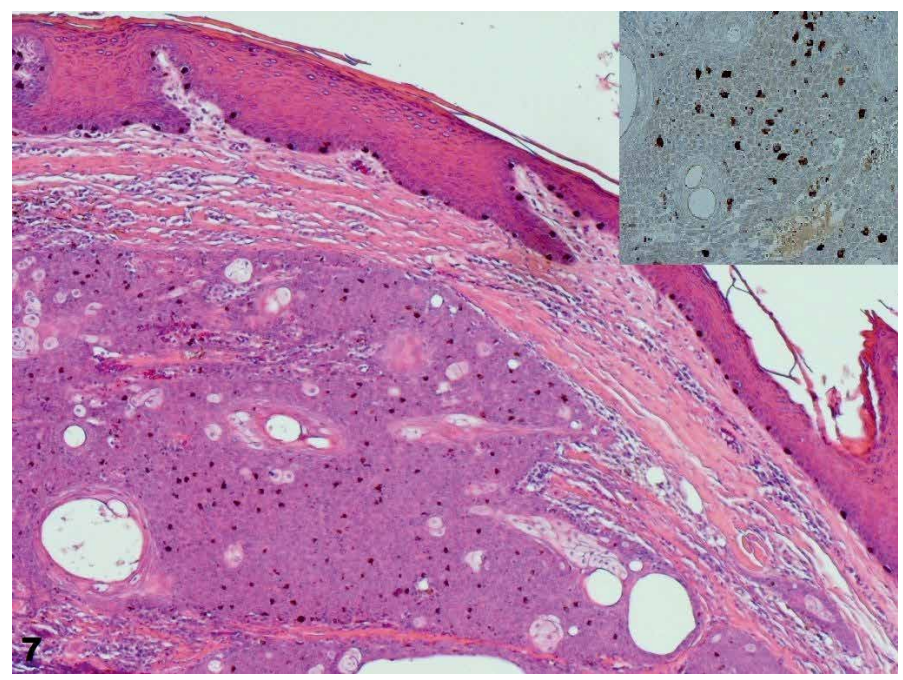

Fig. 7. Melanocytoma $(\mathrm{HE}, 50 \times$, inset down $200 \times$; inset up negative immunostaining for cytokeratin LP34, $200 \times$ )

In the case of hepatoid gland adenoma, the tumor cells occur as lobules (Fig. 5) whereas carcinoma appears as atypical lobulation and intensive vacuolation and creates a small spherical keratin lamination of neoplastic cells. In some cases, among the apocrine and modified apocrine gland tumors, apocrine gland adenoma and carcinoma and ceruminous gland adenoma were diagnosed. Infundibular cysts with a wall composed of stratified squamous epithelium resembling the epithelial cells of infundibulum of hair follicle filled with stratified keratin mass were the most common among the cysts. All metastases to the skin spread from the mammary gland tumors.

The melanocytic tumors of the skin were represented by two melanocytomas composed of melanocytic cells of a different fashion (small spindle-shaped, large spindle-shaped, epithelioid, polygonal and round cells) with an abundant melanin pigment in the cytoplasm, and one melanocytoma composed of melanocytes, morphologically resembling the epithelial cells without a melanin pigment (Fig. 7). As to the tumors of the

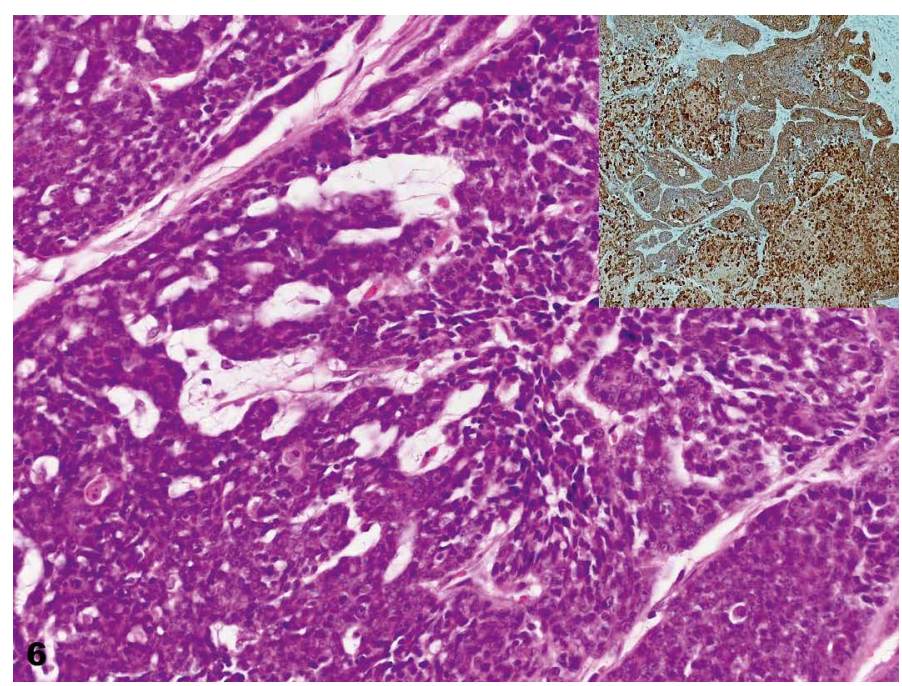

Fig. 6. Metastatic of mammary gland tumours to the skin (HE, $200 \times$; inset positive immunostaining for cytokeratin AE1/AE3, $100 \times$ )

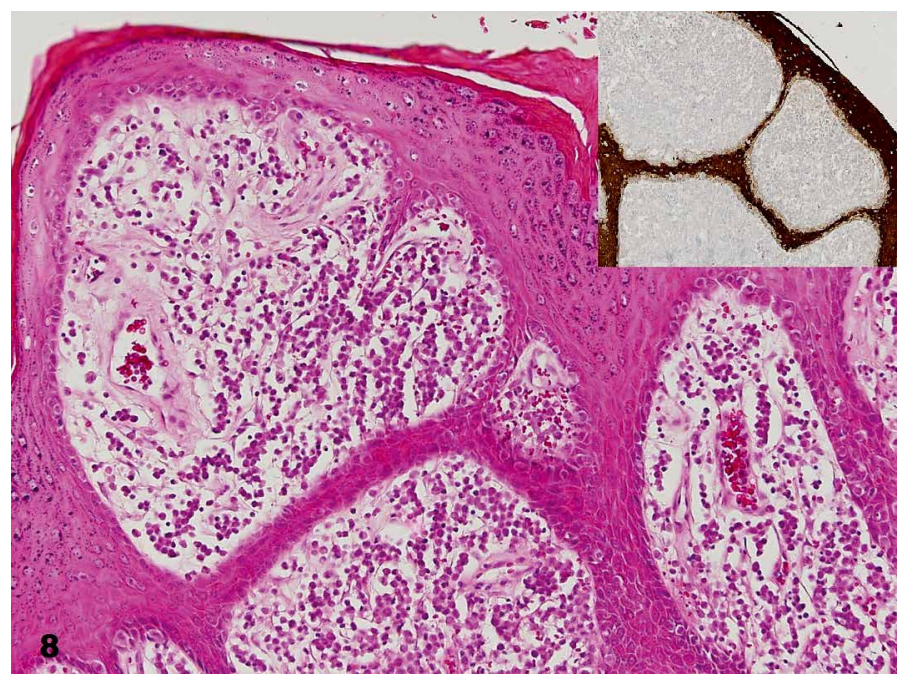

Fig. 8. Canine cutaneous histiocytoma (HE, $100 \times$; inset negative immunostaining for cytokeratin LP34, $100 \times$ )

fibrous tissue, fibroma composed of spindle-shaped fibroblasts in a lengthwise arrangement containing abundant collagen and interwoven to form bundles of fibers, and fibrosarcoma composed of irregularly interwoven (but making no bundles characteristic of fibroma) spindle-shaped cells, were most commonly identified. In most cases of canine cutaneous histiocytoma, the cells grow in packets, chords, in close apposition to the hyperplastic yet thinly stretched overlying epidermis (Fig. 8). A few cases of the canine cutaneous histiocytomas composed of diffused histiocytes or featureless sheets located in the interface of the derma and epidermis with intensive hyperplasia of the epidermis were identified. The most common mast cell tumors (MCTs) identified were of grade II and composed of large round monomorphic cells with abundant basophilic cytoplasm and intracytoplasmic granules (Fig. 9). Stained with toluidine blue, the granules of MCTs turned violet or lightly purple (Figs. 9 and 10). One plasmacytoma, which morphologically resembled MCTs, however, with the nuclei of the tumor cells 


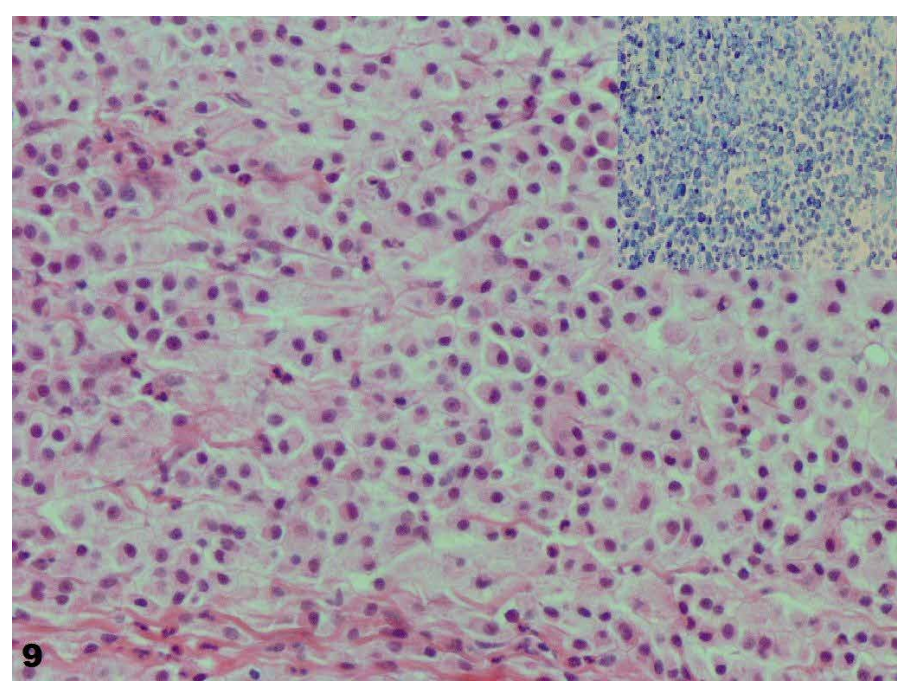

Fig. 9. Mast cell tumor, grade II (HE, $200 \times$; inset Toluidine blue staining for mast cells, $200 \times$ )

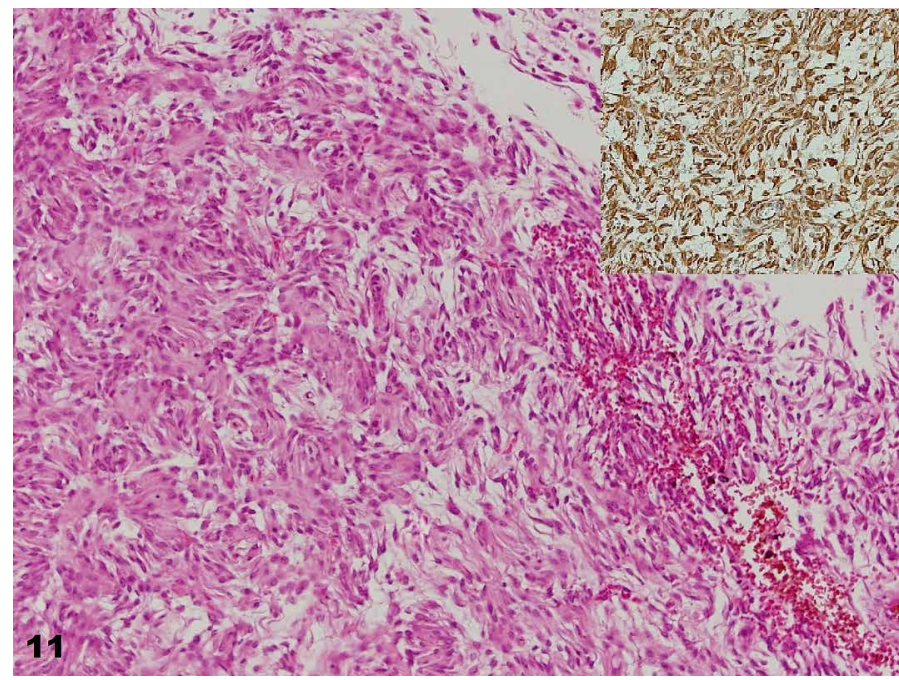

Fig. 11. Fibroma $(\mathrm{HE}, 100 \times$; inset positive immunostaining for vimentin $V 9,200 \times$ )

located on the cell sides and the toluidine blue reaction being negative, was identified. A lipoma composed of spherical, polygonal and variably sized adipocytes with inconspicuous nuclei was most common in the group of adipose tissue tumors. The lipoma was encapsulated in the connective tissue. One infiltrating lipoma was identified: morphologically it resembled a lipoma; however, it was not surrounded by a connective tissue capsule and single adipocytes profusely infiltrated the adjacent surrounding tissues.

Immunohistochemical examination. In the case of squamous cell carcinoma, the cells of epidermis, neoplastic invasive keratinocytes, resembling the stratum spinosum cells accumulation in the derma, and keratin mass in their central parts demonstrated strongly positive immunostaining for antibodies "LP34". In the case of basosquamous carcinoma, strong positive immunostaining for antibodies "LP34" were demonstrated by the accumulations of the hyperplastic keratinising basal cells and the keratinised cells concentrated in their center (Fig. 1). In the case of trichoblastoma (ribbon

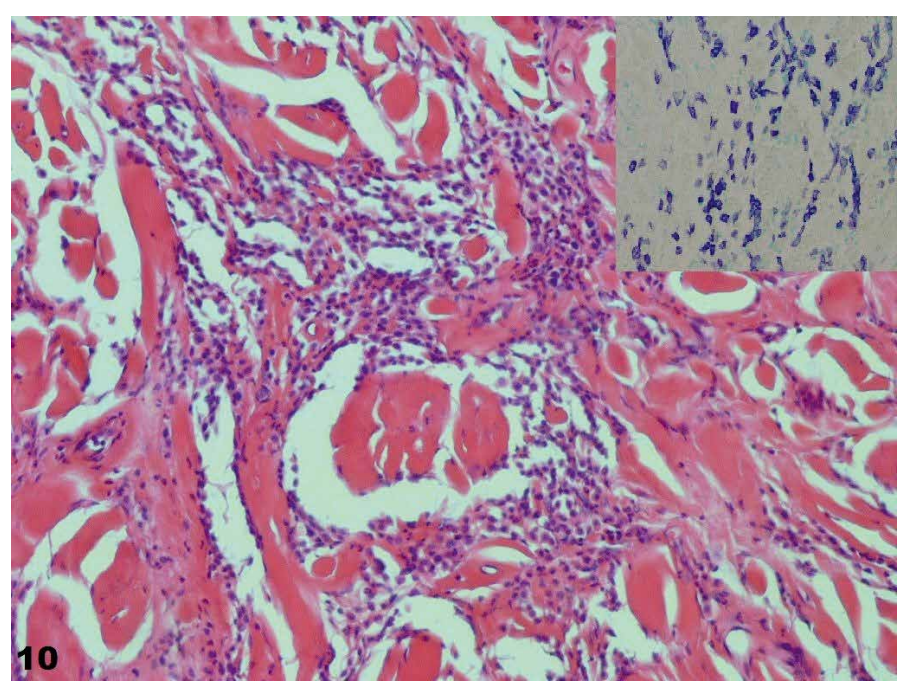

Fig. 10. Mast cell tumor, grade III (HE, $100 \times$, inset Toluidine blue staining for mast cells, $200 \times$ )

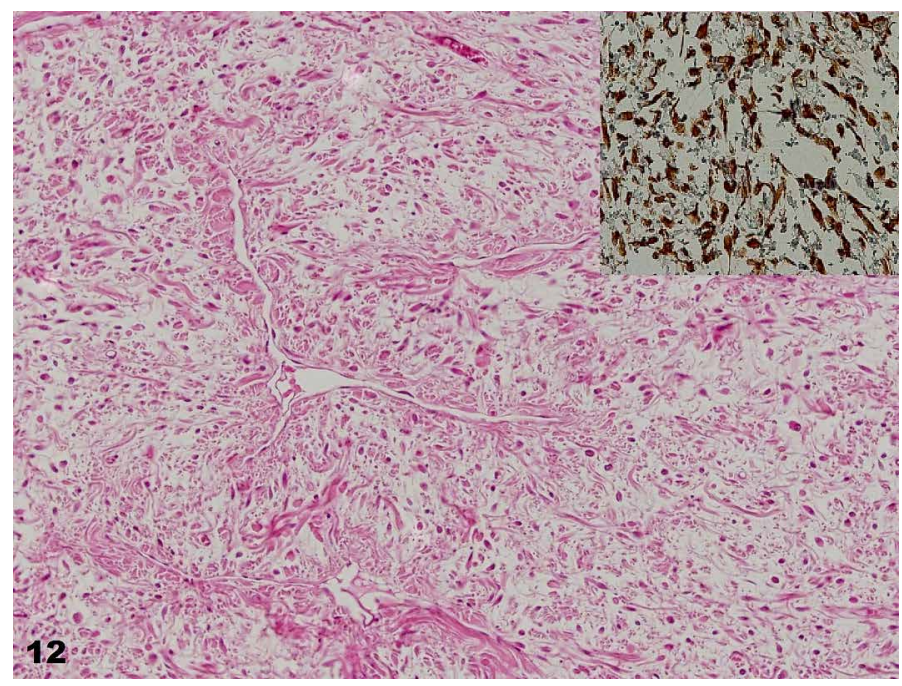

Fig. 12. Fibrosarcoma $(\mathrm{HE}, 100 \times$; inset positive immunostaining for vimentin $\mathrm{V9}, 200 \times$ )

and spindle type), strongly positive immunostaining for antibodies "AE1/AE3" was characteristic of the hyperplastic basal cells (Fig. 2). In cases of trichoepithelioma (Fig. 3), malignant trichoepithelioma (Fig. 4), infundibular keratinizing acanthoma and infundibular cyst strongly positive immunostaining for antibodies "LP34" was shown by the cells located in the external part of the cyst wall, whereas the reaction of the cells located in the internal part of the cyst wall was negative. Moreover, strongly positive immunostaining for antibodies "LP 34" was observed in the keratin mass contained in the cysts. In the case of apocrine adenoma, glandular components demonstrated weak positive immunostaining for antibodies "LP34". In the case of hepatoid gland adenoma (perianal gland adenoma), positive immunostaining for antibodies "LP34" was demonstrated by the skin epidermal and hair follicle cells and the accumulations of the focal squamous cells (Fig. 5). In the samples of metastatic mammary gland tumors in the skin, only keratinocytes indicated strongly positive immunostaining for anti- 
bodies "LP34" whereas the suspected metastatic mammary epithelial cells showed negative immunostaining. However, the antibodies "AE1/AE3" illustrated a strongly positive reaction of keratinocytes and the metastatic mammary epithelial cells (Fig. 6).

In the case of melanocytoma with the cells morphologically resembling the epithelial ones, the immunohistochemical reaction for antibodies "LP34" was negative. Strong positive immunostaining was observed only in the hyperplastic epidermal cells (Fig. 7).

In cases of fibroma (Fig. 11) and fibrosarcoma (Fig. 12), a strongly positive immunohistochemical reaction for antibodies "V9" was observed in the fibrous tissue cells. All cases of a lipoma, fibroma and fibrosarcoma for antibodies "LP34" showed negative immunostaining. In the case of canine cutaneous histiocytoma, strongly positive immunostaining for antibodies "LP34" was observed only in the hyperplastic epidermal cells, forming a reticular structure, whereas the inside accumulations of focal histiocytes demonstrated negative immunostaining (Fig. 8).

The aim of the present study was to examine canine cutaneous tumors histologically and immunohistochemically during routine diagnostics. It was discovered that epithelial and melanocytic tumors were more common $(52.3 \%)$ as compared to mesenchymal tumors $(47.7 \%)$. The results of our research into epithelial, melanocytic and mesenchymal tumors of the skin are in agreement with the results obtained by several authors (Tab. 5). The most frequent cutaneous tumors were tumors with adnexal differentiation (34.6\%), tumors of a fibrous tissue (13.7\%), mast cell tumors (11.8\%), histiocytic tumors (11.8) and tumors of the epidermis $(7.8 \%)$. Similar data were reported by Sharif (28) who stated that the most frequent tumors prevalence of individual groups of cutaneous were tumors with adnexal differentiation (26.6\%), histiocytic tumors $(17.3 \%)$, tumors of a fibrous tissue $(7.7 \%)$, mast cell tumors $(6.9 \%)$, while the data of other authors (6-8, $20,30)$ proved that mast cell tumor, fibrosarcoma and canine cutaneous histiocytoma were most frequent among canine cutaneous tumors.

Walter (31) indicated that cytokeratin (CK6) expression known as 'stress' cytokeratin, was demonstrated in all epidermal samples. Our findings confirmed that antibodies "LP34" used as markers for the neoplastic cells of epithelial origin among the tumors of the epidermis showed a strong expression of cytokeratin $(5 / 6)$ in all cases of squamous cell carcinoma and basosquamous carcinoma, as well as revealing the epithelial origin of neoplastic keratinocytes, basal cells with the foci of squamous cells and keratin pearls. Furthermore, strong expression of cytokeratin (5/6) and the epithelial origin of the keratinising cyst wall cells were confirmed among follicular tumors in all cases of trichoepithelioma, malignant trichoepithelioma, pilomatricoma, and infundibular keratinizing acanthoma. Based on these data and the data described by Kozaki et al. (18) that LP34 recognized only cytokeratin 6 in the healthy canine hair follicle outer root sheath cells, we can assume that strongly positive immunostained tumor cells of the cyst wall originated from the hair follicle outer root sheath cells, whereas the negative immunostained tumor cells of the cyst wall resulted from the hair follicle inner root sheath cells. Our findings confirmed the results obtained by other researchers, which suggest that canine keratinocytes of the epidermis in the basal and suprabasal layers were stained strongly with antibodies LP34 (Ab against CKs 5, 6 and 18) and only the hair matrix cells were stained strongly with antibodies "AE1" $(18,31)$. On the basis of these data, antibodies "AE1/AE3" were used to detect the hair matrix cells in the present work. All cases of trichoblastoma revealed highly positive immunostaining for primary rudimentary hair matrix cells.

Among apocrine and modified apocrine gland tumors, in the case of apocrine adenoma weak positive immunostaining for antibodies "LP34" in the glandular component was confirmed. Similar data proving that antibodies "LP 34" confirm the epithelial origin of the glandular cells have been reported by many researchers $(17,18,27)$.

Our findings confirmed that according to the results of histological examination, the differentiation of primary skin adnexal tumors from metastatic lesions is difficult. Plumb et al. (23) described that CK 5/6 could potentially be of help in distinguishing skin adnexal tumors from most metastatic neoplasms, which do not usually express this marker. Walter (31) described that antibody AE1 immunoreacted with cytokeratin 19. CK 19 has been found to detect glandular epithelial cells in canine mammary tumors. The AE3 antibody has already been used in canine tissue sections to identify the luminal epithelium of the normal mammary gland

Tab. 5. Prevalence of epithelial, melanocytic and mesenchymal tumors of the skin according to different authors

\begin{tabular}{|c|c|c|c|c|}
\hline & $\begin{array}{l}\text { Epithelial tumors } \\
\text { of the skin (\%) }\end{array}$ & $\begin{array}{l}\text { Melanocytic tumors } \\
\text { of the skin (\%) }\end{array}$ & $\begin{array}{l}\text { Mesenchymal tumors } \\
\text { of the skin (\%) }\end{array}$ & $\begin{array}{l}\text { Other tumors localized } \\
\text { in the skin }(\%)^{\mathrm{a}}\end{array}$ \\
\hline Sharif, Germany, 2006 (28) & 49.3 & 5.3 & 45.3 & NR \\
\hline Mukaratirwa et al., Zimbabwe, 2005 (20) & 39.4 & 8.7 & 44.4 & 7.4 \\
\hline Pakhrin et al., Korea, 2007 (22) & \multicolumn{2}{|c|}{56.95} & 38.90 & 4.14 \\
\hline Simeonov et al., Bulgaria, 2011 (29) & \multicolumn{2}{|c|}{58.13} & 18.14 & NR \\
\hline Sostaric-Zuckermann et al., Croatia, 2013 (30) & \multicolumn{3}{|c|}{45.73} & NR \\
\hline
\end{tabular}

Explanation: ${ }^{\mathrm{a}} \mathrm{NR}=$ not reported 
and the epithelial component of mammary tumors, as well as epithelial micrometastases in the regional lymph nodes $(9,27)$. Based on these data, our findings confirmed that antibodies "LP34" revealed negative immunostaining for metastatic glandular epithelial cells whereas antibodies "AE1/AE3" revealed strongly positive immunostaining for metastatic glandular epithelial cells in the suspected cases of metastasis of mammary tumors to the skin.

According to our data, cutaneous melanocytic tumors accounted for $2.0 \%$ of all skin tumors. The analysis of scientific publications showed that researchers differed in classifying the obtained data. In our investigation, with the help of antibodies "LP34" (negative reaction), one melanocytoma, which had a similar morphology to melanoacanthoma, was confirmed. The majority of researchers reported that canine melanocytic tumors were common and accounted for from $5 \%$ to $7 \%$ of all canine skin tumors $(6,16,26)$. The lower prevalence of melanocytic tumors in our investigation $(2.0 \%)$ might have been influenced by the fact that histologically identified tumors were classified as other tumors of similar morphology.

In the present work, the highest prevalence of cutaneous round cell tumors, which were additionally stained with toluidine blue for identification of the mast cells, was identified. The poorly differentiated round cell tumors, which showed a negative reaction to toluidine blue staining, were additionally examined immunohistochemically using antibodies "LP34" to confirm the absence of the epithelial cells. Our research results confirm the data reported by other researchers that histologically, the intracytoplasmic granules typical of MCTs are more difficult to visualize in the tumors with intermediary differentiation and poor differentiation. Such special stain as toluidine blue is used to improve the visibility of these granules $(2,3)$. In many cases, however, the granules are invisible even when histochemical stains are used. Thus, immunohistochemistry becomes a vital tool to help histology provide a more definitive diagnosis of round cell tumors, especially in cases of poorly differentiated MCTs (3).

Vimentin suffers poor specificity for mesenchymal neoplasms because it may be coexpressed with CK in a wide range of carcinomas. Therefore, vimentin by itself cannot be used to differentiate mesenchymal from non-mesenchymal tumors $(4,21)$. In our investigation, fibromas and fibrosarcomas were analyzed immunochemically using antibodies "V9".

In the present work, additional immunostaining of fibroma and fibrosarcoma (with a positive reaction to antibodies "V9") using antibodies "LP34" revealed the absence of epithelial cells and proved the specificity of antibody "V9" to vimentin. Therefore, according to Goodpaster et al. (15), fibroblasts can take on a wide array of shapes in different tissues, whereas vimentinpositive cells that are not fibroblasts, including macrophages, can also have a spindle-shaped appearance.
In conclusion, the results obtained in this study indicate that the routine histological examination of canine cutaneous tumors enables an easy and straightforward differentiation of the main epithelial and mesenchymal tumors to be made. The canine cutaneous epithelial and melanocytic tumors were more common $(52.3 \%)$ than the mesenchymal tumors $(47.7 \%)$. The routine histopathological diagnosis of main cutaneous epithelial, melanocytic and mesenchymal tumors depends largely on histological features; however, in some cases, an immunohistochemical examination is needed for definitive diagnosis. Staining round cell tumors with toluidine blue may give valuable information on the mast cell tumors. Immunohistochemistry could be very helpful in diagnosing melanocytic tumors without pigments, it is recommended to use specific antibodies for melanocytes. Antibodies "LP34" are useful in detecting epithelial cells in the canine cutaneous tumors. Antibodies "AE1/AE3" could be helpful for finding metastatic glandular epithelial cells in the skin. Also, antibodies "V9" could be a useful tool to diagnose cutaneous tumors consisting of fibrous tissue cells.

Acknowledgements: All authors would like to thank the Medical Academy Studies Foundation of Lithuanian University of Health Sciences and National Food and Veterinary Risk Assessment Institute for the funded histopathological and immunochemical investigations of canine skin, adnexal and subcutaneous tissues tumours.

\section{References}

1. Alhumaidi A.: Practical immunohistochemistry of epithelial skin tumor. Indian J. Dermatol. Venereol. Leprol. 2012, 78, 698-708.

2. Alketa Q., Letizia P., Brunilda M., Eglantina X., Luljeta D.: Spontaneous skin canine tumors: toluidine blue stain detection of mast cells in tissue section. Albanian J. Agric. Sci. 2014, 13, 391-394.

3. Araujo M. R., Preis I. S., Lavalle G. E., Cassali G. D., Ecco R.: Histomorphological and immunohistochemical characterization of 172 cutaneous round cell tumours in dogs. Pesqui Vet. Bras. 2012, 32,772-780.

4. Bahrami A., Truong L. D., Ro J. Y.: Undifferentiated tumor true identity by immunohistochemistry. Arch. Pathol. Lab. Med. 2008, 132, 326-348.

5.Bedir R., Sehitoglu I., Yurdakul C., Saygin I., Ustuner P., Dilek N.: The importance of cytokeratin 19 expression in the differentiation of Basal cell carcinoma and trichoepithelioma. J. Clin. Diagn. Res. 2015, doi:10.7860/ JCDR/2015/10915.5414.

6. Boerkamp K. M., Teske E., Boon L. R., Grinwis G. C., Bossche L. van den, Rutteman G. R.: Estimated incidence rate and distribution of tumours in 4,653 cases of archival submissions derived from the Dutch golden retriever population. BMC Vet. Res. 2014, doi: 10.1186/1746-6148-10-34.

7. Bronden L. B., Eriksen T., Kristensen A. T.: Mast cell tumours and other skin neoplasia in Danish dogs - data from the Danish Veterinary Cancer Registry. Acta Vet. Scand. 2010, doi:10.1186/1751-0147-52-6.

8. Chikweto A., McNeil P., Bhaiyat M. I., Stone D., Sharma R. N.: Neoplastic and nonneoplastic cutaneous tumors of dogs in Grenada, West Indies. ISRN Vet. Sci. 2011, doi: 10.5402/2011/416435.

9. Clemente M., Perez-Alenza M. D., Illera J. C., Pena L.: Histological, immunohistological and ultrastructural description of vasculogenic mimicry in canine mammary cancer. Vet. Pathol. 2010, 47, 265-274.

10. Dennis M. M., McSporran K. D., Bacon N. J., Schulman F. Y., Foster R. A., Powers B. E.: Prognostic Factors for Cutaneous and Subcutaneous Soft Tissue Sarcomas in Dogs. Vet. Pathol. 2011, 48, 73-84.

11. Fuchs E.: Keratins and the skin. Annu. Rev. Cell Dev. Biol. 1995, 11, 123-153.

12. Fuertes L., Santonja C., Kutzner H., Requena L.: Immunohistochemistry in Dermatopathology: A Review of the Most Commonly Used Antibodies (Part I). Actas Dermosifiliogr. 2013, 104, 99-127.

13. Fuertes L., Santonja C., Kutzner H., Requena L.: Immunohistochemistry in dermatopathology: a review of the most commonly used antibodies (Part II). Actas Dermosifiliogr. 2013, 104, 181-203. 
14. Gladilin E., Gonzalez P., Eils R.: Dissecting the contribution of actin and vimentin intermediate filaments to mechanical phenotype of suspended cells using high-throughput deformability measurements and computational modeling. J. Biomechanics. 2014, 47, 2598-2605.

15. Goodpaster T., Legesse-Miller A., Hameed M. R., Aisner S. C., RandolphHabecker J., Coller H. A.: An immunohistochemical method for identifying fibroblasts in formalin-fixed, paraffin-embedded tissue. J. Histochem. Cytochem. 2008, 56, 347-358.

16. Han J. I., Kim D. Y., Na K. J.: Dysregulation of the Wnt/ $\beta$-Catenin signaling pathway in canine cutaneous melanotic tumor. Vet. Pathol. 2010, 47, 285-291.

17. Jasik A., Kozaczynski W., Reichert M.: Canine skin tumours with adnexal differentiation: histopathology and immunohistochemistry. Bull. Vet. Inst. Pulawy 2009, 53, 277-283.

18. Kozaki M., Nakamura Y., Iguchi M., Kano R., Watanabe S., Fujiwara K., Hasegawa A.: Immunohistochemical analysis of cytokeratin expression in dog skin. J. Vet. Med. Sci. 2001, 63, 1-4.

19. Lane E. B., McLean W. H. I.: Keratins and skin disorders. J. Pathol. 2004, 204, 355-366.

20. Mukaratirwa S., Chipunza J., Chitanga S., Chimonyo M., Bhebhe E.: Canine cutaneous neoplasms: prevalence and influence of age, sex and site on the presence and potential malignancy of cutaneous neoplasms in dogs from Zimbabwe. S. Afr. vet Ver. 2005, 76, 59-62.

21. Painter J. T., Clayton N. P., Herbert R. A.: Useful immunohistochemical markers of tumor differentiation. Toxicol. Pathol. 2010, 38, 131-141.

22. Pakhrin B., Kang M., Bae I., Park M., Jee H., You M., Kim J., Yoon B., Choi Y., Kim D.: Retrospective study of canine cutaneous tumors in Korea. J. Vet. Sci. 2007, 8, 229-236.

23. Plumb S. J., Argenyi Z. B., Stone M. S., De Young B. R.: Cytokeratin 5/6 Immunostaining in cutaneous adnexal neoplasms and metastatic adenocarcinoma. Am. J. Dermatopathol. 2004, 26, 447-451.
24. Ramms L., Fabris G., Windoffer R., Schwarz N., Springer R., Zhou C., Lazar J., Stiefel S., Hersch N., Schnakenberg U., Magin T. M., Leube R. E., Merkel R., Hoffmann B.: Keratins as the main component for the mechanical integrity of keratinocytes. Proc. Natl. Acad. Sci. USA 2013, 110, 18513-18518.

25. Ramos-Vara J. A., Kiupel M., Baszler T., Bliven L., Brodersen B., Chelack B., Czub S., Piero F. D., Dial S., Ehrhart E. J., Graham T., Manning L., Paulsen D., Valli $V$. E., West K.: Suggested guidelines for immunohistochemical techniques in veterinary diagnostic laboratories. J. Vet. Diagn. Invest. 2008, 20, 4393$-4413$.

26. Rothwell T. L. W., Howlett C. R., Middleton D. J., Griffiths D. A., Duff B. C.: Skin neoplasms of dogs in Sydney. Aust. Vet. J. 1987, 64, 161-164.

27. Sassi F., Sarli G., Brunetti B., Morandi F., Benazzi C.: Immunohistochemical characterization of mammary squamous cell carcinoma of the dog. J. Vet. Diagn. Invest. 2008, 20, 766-773.

28. Sharif M. A. M.: Epidemiology of skin tumor entities according to the new WHO classification in dogs and cats. Doctoral dissertation, VVB Laufersweiler Verlag, Faculty of Veterinary Medicine. Justus Liebig University Giessen. Germany 2006.

29. Simeonov R., Borissov I., Hubenov H., Dinev D., Dinev I., Simeonova G., Goranov N., Paskalev M., Krastev S., Todorova I., Chaprazov T., Roidev R.: Prevalence of canine epithelial, melanocytic and mesenchymal tumours of the skin and soft tissues: A 10-year study. Bulg. J. Vet. Med. 2011, 14, 171-178.

30. Sostaric-Zuckermann I. C., Severin K., Hohsteter M., Artukovic B., Beck A., Kurilj G. A., Sabocanec R., Dzaja P., Grabarevic Z.: Incidence and types of canine tumours in Croatia. Vet. Arhiv. 2013, 83, 31-45.

31. Walter J. H.: Cytokeratins in the canine epidermis. Vet. Dermatol. 2001, 12, 81-87.

Corresponding author: Donatas Šimkus, Tilzes Str. 18, LT-47130 Kaunas, Lithuania; e-mail: dsimkus@vet.lt 